\title{
Innovation and Sustainability in the Supply Chain of a Cosmetics Company: a Case Study
}

\author{
André Pereira de Carvalho' José Carlos Barbieri²
}

\begin{abstract}
The article analyses the induction process of technological innovations that consider economic, social and environmental concerns throughout the supply chain, in accordance with the proposals of sustainable development. Specifically, it examines the role of focal companies as innovation inductors for their supply chains. The article presents a debate with regards to innovation, sustainability and supply chain management and analyses the concept of sustainable innovation, as well as management models that bridge the gap between these themes. A case study conducted with a cosmetics company of Brazilian origin and presence in Latin America, is presented. This case study demonstrates that sustainable innovation driven by the focal company requires the engagement of its suppliers in order to reduce the negative social and environmental impacts throughout the product's life cycle. Moreover, it illustrates that is possible to implement innovations that generate net social and environmental benefits for all members of the supply chain.
\end{abstract}

Keywords: innovation; sustainability; sustainable supply chain; sustainable innovation; cosmetics industry

\footnotetext{
'São Paulo Business Administration School of Fundação Getulio Vargas (FGV-EAESP), Department of Production and Operations Administration (POI). Avenida Nove de Julho 2029, Bela Vista, São Paulo, SP, 01 3 I 3-902, Brazil. Tel: +55 (I I) 3799-7780.

E-mail: andre.carvalho@fgv.br

${ }^{2}$ São Paulo Business Administration School of Fundação Getulio Vargas (FGV-EAESP), Department of Production and Operations Administration (POI). Avenida Nove de Julho 2029, Bela Vista, São Paulo, SP, 0 I 3 I 3-902, Brazil. Tel: +55 (I I) 3799-7780.

E-mail: jose.barbieri@fgv.br
}

ISSN: 07 I8-2724. (http://www.jotmi.org)

Journal of Technology Management \& Innovation (C) Universidad Alberto Hurtado, Facultad de Economía y Negocios. 


\section{Introduction}

The term supply chain management (SCM) was used throughout the 1980s to describe the flow of materials between organizations and, accordingly, understood initially to be a synonym of logistics, an extension of the concept of logistics or even a set of activities and processes related to the integration of businesses that clearly pointed to something beyond the concept of logistics. Toward the end of the 1990s, SCM was re-conceptualized to incorporate all business processes, spanning across the organizations that compose a supply chain, as explained by Cooper et. al. (1997, p. 2). According to these authors, SCM "is the integration of business processes from end user through original suppliers that provides products, services and information that add value for customers." The goal of supply chain management is to achieve a more profitable outcome for all tiers of the chain, which represents a significant challenge as the selfinterest of the individual players must be subordinated to the benefits generated for the chain as a whole (Carvalho and Barbieri, 2010).

Green supply chain management (GSCM) was established within the field of research as the most appropriate approach for the insertion of environmental concerns into SCM. GSCM is the incorporation of the environmental viewpoint into SCM and includes activities such as the green design of a product, the adoption of environmentally-friendly materials, cleaner production processes, end-of-life product management after its useful life and other practices that aim to reduce the negative ecological impacts of production without sacrificing quality, cost, reliability and other performance objectives (Srivastava, 2007, p. 54). The implementation of GSCM includes activities such as providing design specification to suppliers involving environmental requirements, auditing suppliers' environment management systems, cooperating with suppliers for eco-design, and handling product returns from customers, which range from product defects to the end of a product's useful life (Sarkis, et. al., 20I I). The analytical basis for the realization of GSCM practices is the life-cycle analysis of a product, understood as the steps undertaken by the product from the extraction of raw materials and energy sources to the disposal of the product, considering all possibilities of use.According to ISO 14040, life cycle is the "consecutive and interlinked stages of a product system, from raw material acquisition or generation from natural resources to final disposal" (ISO, 2006).

The need to consider a product's entire life cycle in order to analyze its positive and negative, as well as its social and environmental impacts, raises the first questioning regarding the contributions to sustainability that may be achieved through SCM. Even though parts of the supply chain may not be managed upstream or downstream by the focal com- pany, which coordinates the supply chain, the chain exists and consequently, so does all of its impacts. For example, upstream, a focal company in the textile sector may judge it unnecessary to monitor or integrate the supply of cotton with the farmers that plant the cotton. Similarly, an automobile manufacturer may prefer to not extend its integration efforts to the mining company. Downstream, the delivery of a product or service to the client may be the end point of the SCM; however, impacts relative to the use and postconsumption of the product continue to occur.

Throughout the second half of the $2010 \mathrm{~s}$, there was a more evident evolution of the sustainable supply chain management (SSCM) field of research. From a perspective of standalone research of the interfaces between environmental and economic dimensions, a convergence to a triple bottom line approach was established, which contributed to the emergence of SSCM as a theoretical framework (Carter and Easton, 20II). This convergence process gained significant momentum during 2008 , catalyzed by the publication of two conceptual SSCM frameworks. Based on prior research on sustainability within the intra-organizational scope, Carter and Rogers (2008, p.368) define SSCM as:

"the strategic, transparent integration and achievement of an organization's social, environmental, and economic goals in the systemic coordination of key interorganizational business processes for improving the long-term economic performance of the individual company and its supply chains".

Additionally, founded on a broad research study dealing with social and environmental concerns in the inter-organizational scope, Seuring and Müller (2008, p. 1700) define SSCM as:

"the management of material, information and capital flows as well as cooperation among companies along the supply chain while taking goals from all three dimensions of sustainable development, i.e., economic, environmental and social, into account which are derived from costumer and stakeholder requirements".

\section{Sustainable Innovation}

Agenda 2I, one of the founding documents of the sustainable development movement, states that unsustainable production and consumption standards, particularly in industrialized countries, constitute the main causes of uninterrupted deterioration of the environment, which has been profoundly altered by the means through which humanity transforms natural resources into goods and services that tend to its necessities, whatever these may be. As such, it is recommended that special attention be given to the demand for natural resources that is generated by the current system of production and consumption, which is to say that special attention be given to innovation of any sort: products, pro- 
cesses, management frameworks and businesses. It is no overstatement to say that innovation continually shapes the physical, biological and social environments. If innovation has contributed to the state of degradation that is noticed today, the possibility of reverting the current situation also relies on innovation. To move towards a sustainable system of production and consumption, innovation models must take into account the requirements of sustainable development.

For companies in general, these requirements translate into economic, social and environmental sustainability. Elkington (2000, p. 2I) defines sustainability as "the principle of ensuring that our actions today do not limit the range of economic, social, and environmental options open to future generations." For Savitz and Weber (2006, p. x), sustainability "is 'the art of doing business in an interdependent world' and a sustainable corporation is one that creates profits for its shareholders while protecting the environment and improving the lives of those with whom it interacts." Thus, the innovations proposed by a company willing to tread the path of sustainability must incorporate these requirements.

The emphasis on economic outcomes is part of the conventional practice of companies with respect to their innovation. Typical performance indicators of innovation in the business environment are estimated economic results, which include: increase in revenues, profits, market share, etc. The insertion of environmental concerns into innovation processes is an important step. For Kemp and Arundel (1998) environmental innovation consists of new or modified processes, techniques, systems and products to avoid or reduce environmental harms and can be classified into 6 types: (i) Pollution control technologies (end-of-pipe technologies), (ii) Clean-up technologies to remedy damages that have already occurred, (iii) Waste management technologies, (iv) Recycling technologies, (v) Clean technologies related to production processes and (vi) Clean products or products that have a small environmental impact throughout their life cycle.

Type I through 4 innovations, in general, are performed by what is called the environmental industry, consisting of equipment manufacturers, facilities and products intended to resolve environmental problems generated by other corporations, as well as service corporations in consulting, transport, storage, etc. In general, they are innovations that resolve environmental problems created by current products and processes and, as such, have a corrective function. Type 5 and 6 innovations are preventive, that is, they alter products and processes or substitute them with the intent of preventing the emergence of adverse environmental impacts or of reducing their intensity. Note that for Type 6 innovations, there is a mention of the product's life cycle, a needed provision, as the impacts of the product occur in all tiers of the supply chain, from the extraction of the raw material to the use of the product to post-consumption. As such, from an environmental perspective, it does not make sense to transfer the negative impacts between the tiers of the chain as the final result will be the same since the problems would simply change places.

Kemp and Pearson (2008, p.7) reinforce the need to consider the life cycle. Expanding the technological product and process (TPP) innovations from the Oslo Manual (OECD, 1992), these authors define eco-innovation as:

"production, assimilation or exploitation of a product, production process, service or management or business method that is novel to organization (developing or adopting it) and which results, throughout its life cycle, in a reduction of environmental risk, pollution and other negative impacts of resources use (including energy use) compared to relevant alternatives." (our emphasis)

Eco-innovation combines two dimensions of sustainability, economic and environmental; namely, it refers to eco-efficiency, a management concept that seeks to reach economic and environmental benefits simultaneously and in a balanced manner. This type of innovation is aligned with GSCM, as mentioned previously. Nevertheless, it is possible for negative social aspects to be associated with eco-innovation; for example, the replacement of one productive input obtained from a non-renewable source for another obtained from a renewable source may encourage land concentration and child labor as a means of meeting the increase in demand for the input. The company obtains positive economic outcomes from this innovation and the environment benefits from the reduction in the extraction of non-renewable sources; however, from a social viewpoint, a negative impact was generated. As such, eco-innovation that meets the principles of eco-efficiency is insufficient for the innovation to be considered sustainable.

Sustainable innovation is, therefore, eco-innovation as defined above, enlarged by a concern for negative social impacts. Taking into consideration the aforementioned definition of eco-innovation, Barbieri et al. (2010, p. I5I) define sustainable innovation as:

"the introduction (production, assimilation or exploitation) of products, production processes, management or business methods, new or significantly improved, that bring economic, social and environmental benefits when compared with relevant alternatives."

The evaluation of economic, social and environmental impacts should take into account a product's life cycle, which is configured along the entire supply chain, as stated previously. Thus, to complement the definition above, sustain- 
able innovation is the introduction of products, production processes, management or business methods, new or significantly improved, that bring economic, social or environmental outcomes, considering the supply chain and compared with relevant alternatives.

\section{Induction of Social and Environmental Practices in Supply Chains}

The pursuit of significant social and environmental benefits in conjunction with economic objectives that generate profitable results for all members of the supply chain is what turns a supply chain sustainable. For Seuring and Müller (2008), the insertion of sustainability in the supply chain occurs because of pressures and incentives from different external groups outside of the chain positioned on the demand-side: costumers, different levels of government, from municipal to national to multinational, and stakeholders, described as other participants with an interest in the supply chain, as demonstrated by Figure I. When the focal company is the object of pressures, such as new legal requirements, client demand or stakeholder demand, it frequently transfers these pressures to its supply chain. If the pressures deal with the product's life cycle and/or members of the chain with which the company does not have a direct relationship, the focal company will need to evaluate more distant levels of its supply chain in order to offer answers or solutions to those that demand them; this behavior is not justified by a decision founded purely in the economic dimension.
Pressures and incentives for the adoption of sustainability practices affect collaboration with suppliers, from the obtainment of information dealing with social and environmental concerns regarding the production of suppliers in tiers found in the beginning of the chain (ie. production of raw materials) to the search for performance improvements of key suppliers that are closer to the focal company. The main barriers to the internalization of sustainability practices within the supply chain by a focal company are: (i) increase in management costs, (ii) greater coordination efforts in a more complex environment and (iii) insufficient or inexistent communication in the chain. On the other hand, the main supporting factors for the internalization of sustainability are:

I. management systems focused on the environment and on social practices;

2. monitoring, evaluation, reporting and implementation of sanction models to suppliers, as a means of encouraging the improvement of social and environmental performance at risk of losing the contract for unsatisfactory performance;

3. training of social and environmental concerns for the purchasing department of the focal company as well as of its suppliers;

4. communication regarding sustainability throughout the chain; and

5 . integration of sustainability objectives in the policies of the focal company, such as additional targets for social and environmental performance for the purchasing team.

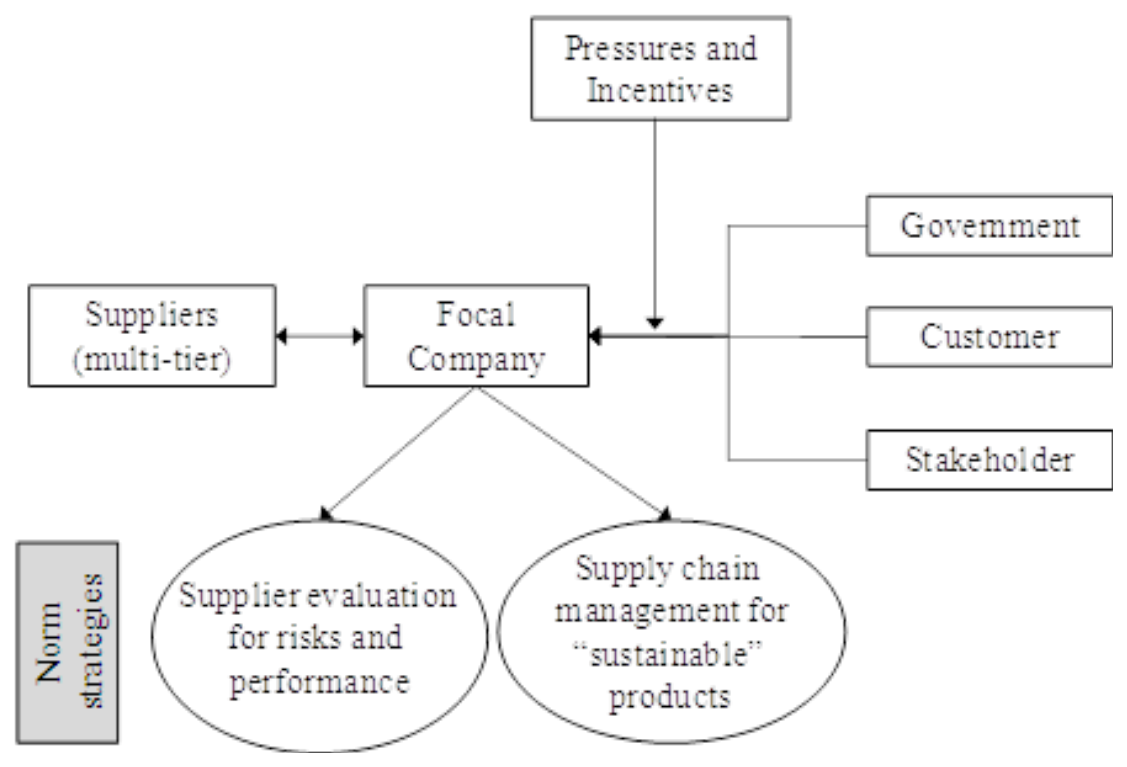

Figure I -Triggers for sustainable supply chain management Source: Seuring and Müller (2008)

ISSN: 07 I8-2724. (http://www.jotmi.org) 
Focal companies deal with such pressures and incentives in different manners, with the most common of these being approaches that focus on turning the productive process greener by means of guarantees that more appropriate social and environmental approaches are being adopted throughout the chain that is the object of the pressures. A second approach is characterized by a focus on a sustainable product, but also reflects positively on the productive process. Accordingly, these two approaches define two types of implementation strategies for the SSCM, as will be shown below.

\section{I Supplier Risk and Performance Evaluations}

The supplier management risk and performance (SMRP) strategy by Seuring and Müller (2008) focuses on adapting the production process to more rigorous social and environmental demands than those adopted by the supply chain in a given time. The focal company, in order to prevent reputational risks or to salvage the organization's image after damage has already occurred, implements and intensifies social and environmental criteria to the supplier evaluation process. Social and environmental standards, such as environmental management systems, health and work safety systems, social responsibility systems and other third-party certifications, play a crucial role in this approach, which can also elaborated from supplier self-assessment and supplier commitment to the social and environmental impacts of its operations.

Among the supporting factors listed, communication and training from the focal company are measures aimed at improving the relationship with suppliers throughout the chain. The establishment of minimum requirements in the supply chain by the focal company usually surpasses the objective of reducing reputational risk associated with social and environmental problems, also generating positive results with regards to the management of the risk of operational disruptions, such as interruptions in the supply of materials, delivery delays and others commonly treated in conventional literature of supply chain management. The intensification of supplier evaluation and monitoring activities still results, in various cases, in the improvement of supply chain performance as a whole, due to the exploration of win-win opportunities, frequently presented in management and sustainability literature restricted to the economic and environmental dimensions. Suppliers tend to perceive the social and environmental criteria imposed by the focal company as pre-requisites to continue in the supply chain. This encourages suppliers to act in accordance with the minimum requisites defined, even in cases in which the focal company that establishes the requisites is not the supplier's main client (Seuring and Müller, 2008).

\subsection{Supply Chain Management for Sustainable Products}

The strategy of supply chain management for sustainable products (SCMSP) has as its objective client satisfaction and the obtainment of a competitive advantage for the focal company, and consequently its supply chain, in the market. The aim, in addition to a more sustainable production process, is sustainable products, that for Seuring and Müller (2008, p. 1705) are considered any type of product with an improved environmental and social quality, a different way of defining sustainable innovation. Joint initiatives between the focal company and its suppliers may be critical for the implementation of a supply chain focused on sustainable products; hence, the collaboration/cooperation between the focal company and the members of the chain, from raw materials to the final consumer, is more demanded in this than in the previous strategy, SMRP. As the authors state, there seems to be a need for cooperation among a wider range of companies throughout the chain than is usually discussed in conventional supply chain management literature (Seuring and Müller, 2008, p. 1705). In other words, the need for cooperation extends beyond first-tier suppliers, defined as those members of the chain who have a direct relationship with the focal company.

It may be necessary, even when there is a development of suppliers prior to the sale of the sustainable product by the focal company, that the company also allocate considerable investments in the structuring of suppliers in periods in which suppliers are not prepared to meet the standards of the production process, even less so, the final product. A supplier may be trained to improve its performance, including in situations in which the focal company will not purchase more than $10 \%$ of its final production. This process still demands a more intense flow of information throughout the supply chain: suppliers need more detailed information regarding the subsequent stages of the supply chain and the product's life cycle in order to understand why the requirements placed upon them must be met.

It should be noted that SMRP and SCMSP strategies are not opposing but rather, ambivalent: although simultaneously distinguishable within an organization, they may support one another, thereby strengthening SSCM by the focal company. Even though the second strategy, due to its greater complexity, may be viewed as the result of a maturity process of the focal company, the opposite scenario must also be found (Seuring and Müller, 2008b). In summary, in sustainable supply chains, it is expected that environmental and social criteria be met by its members in order for them to continue in the chain and, at the same time, that the company's competitiveness be maintained through the fulfillment of client needs and related economic criteria (Seuring and Müller, 2008). 


\subsection{Sustainability in Supply Chains and Innovation Strategies}

The Seuring and Müller (2008) framework focuses on the insertion process of sustainability in supply chains and serves as a basis for the Van Bommel (20II) proposal and the analysis of the insertion of sustainability in supply chains from an innovation perspective. This author incorporates an innovation component into the Seuring and Müller (2008) framework and presents a framework for the insertion of sustainability in supply chains from this perspective (Figure 2 ). The innovative power of a focal company and its supply chain influences the manner in which stakeholder pressure regarding innovation is treated and the innovations that result from this process.

External pressure and incentives may not find in the focal company or its supply chain a culture of innovation; in other words, there may not be innovation strategies that occur because of external demands for sustainability. In addition to the focal company's general characteristics, such as size and bargaining power, two characteristics are recognized in SCM literature: innovation power is affected firstly, by the innovative characteristics of the focal company and secondly, by the cooperative characteristics of its supply chain, which include factors like trust, reputation, joint programs and cooperative informational systems throughout the supply chain. The inter-relationships between these characteristics, the pressures and the incentives lead sustainability implementation strategies. According to Van Bommel (20II), three implementation strategies are addressed:

I. Resign: the focal company decides not to start the process of implementation of sustainability practices in the supply chain because of a low level of innovation power or the perception that pressures and incentives are not representative;

2. Defensive: the focal company prioritizes the establishment of environmental requirements throughout the supply chain, equivalent to the SMRP strategy mentioned previously;

3. Offensive: the focal company emphasizes cooperation in its supply chain for innovation toward sustainability, equivalent to the SCMSP strategy

Using the resign strategy, the focal company seeks to survive by adopting "palliative" attitudes toward sustainability, more focused on social philanthropy, or through greenwashing. Unlike the other two, this is not a sustainability strategy. The defensive strategy is anchored on supplier evaluation while the offensive strategy is anchored on supplier development and cooperation with the focal company for the development of new, sustainable products and services. The positive impact of these activities can be evaluated with regard to

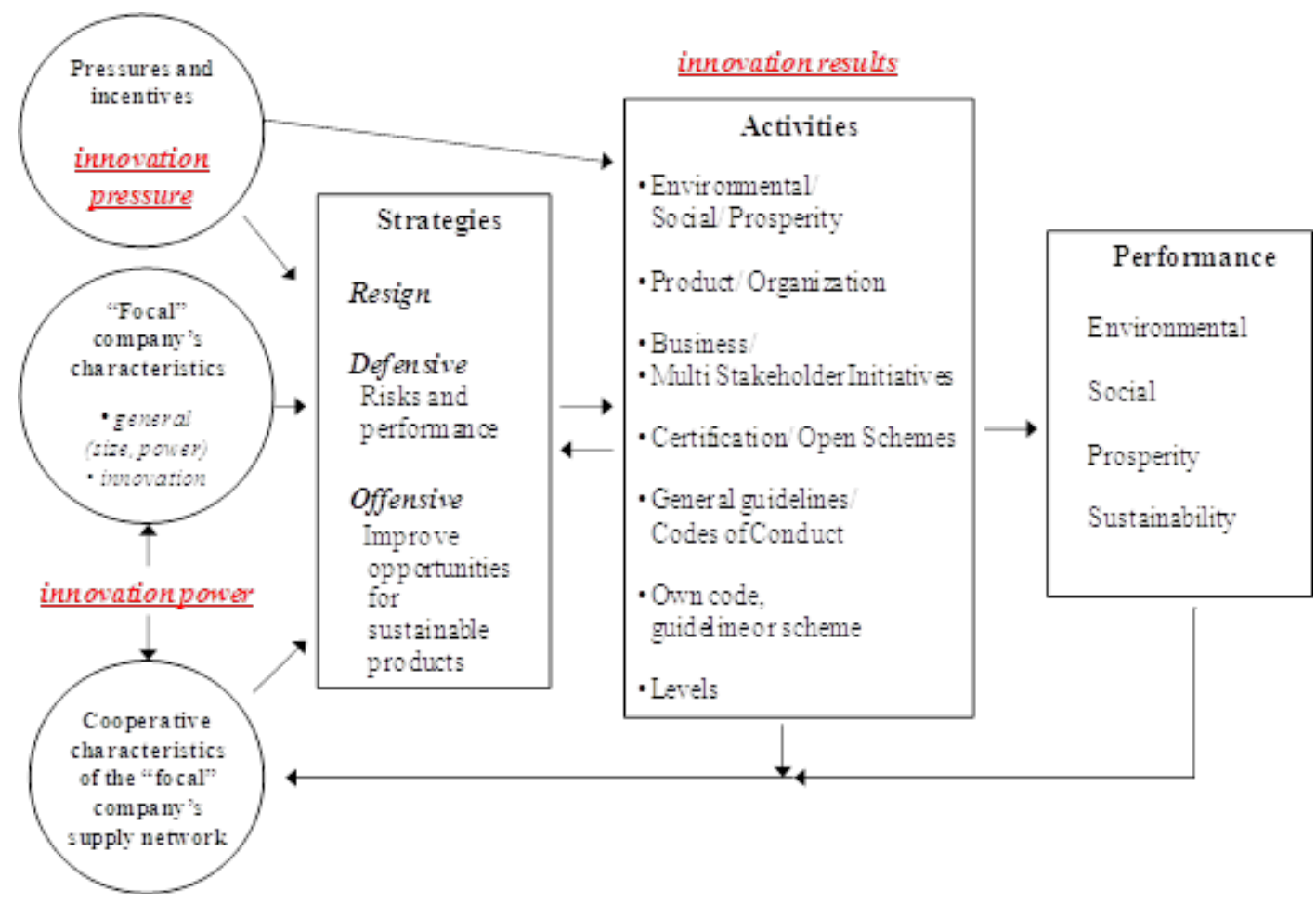

Figure 2 - The implementation of sustainability in supply chains from an innovation perspective Source:Van Bommel (20II)

ISSN: 07I 8-2724. (http://www.jotmi.org)

Journal of Technology Management \& Innovation (C) Universidad Alberto Hurtado, Facultad de Economía y Negocios. 
their contribution toward the reduction of adverse social and environmental impacts or to the generation of sustainable value to all members of the supply chain and to society. Van Bommel stresses that defensive and offensive strategies are ambivalent, using an approach similar to that of Seuring and Müller (2008), SMRP and SCMSP, respectively. The same company is able to adopt the offensive strategy for a line of products and the defensive strategy for another line of products. Both perform a set of activities related to products that lead to innovative outcomes for the supply chain; for example, social and environmental labels that emphasize specific aspects of sustainability, such as fair trade, sustainable management of natural resources, no child labor and others that address inter and intra-organizational matters, able to reach, in certain cases, the entire supply chain.

\section{Methodology}

This work fits into the field of case studies and its design is based in Yin (1994) and Eisenhardt (1989), who affirm that this strategy is widely used by researchers who seek to answer questions that ask "how" and "why" regarding phenomena linked to contemporary facts, which occur in contexts in which there is little possibility of control of the events studied. In this work, an interpretative approach is utilized, which is to say the object of this case study is the understanding of "how" induction occurs for a focal company with technological innovations that take into account economic, social and environmental aspects throughout a supply chain. The unit of analysis is the induction of sustainability practices within the supply chain. The collection of data took place through the use of secondary data and through semi-structured interviews with the employees of the analyzed focal company, in this case, Natura Cosméticos (Natura). For the construction of the Natura case study, four employees were interviewed in the departments of innovation (2), sustainability (I) and operations (I).

Unquoted information throughout the case study refers to data collected in interviews with representatives of the focal company. When secondary data was unavailable to be compared with data provided by the interviewees, the best available information was utilized. In accordance with the recommendation of Yin (1994), the questions that support the case description in this work were divided into the following segments: (i) sustainable business politics and internal practices, innovation (ii) in products, (iii) in production processes and (iv) organizational processes, and (v) sustainability outcomes regarding social and environmental objectives.

\section{Case Study:}

Natura is a company of Brazilian origin, founded in 1969, that operates in the Cosmetic, Toiletry and Fragrance Industry. In addition to Brazil, the company has operations in the following countries: France, Argentina, Chile, Columbia, Mexico and Peru. The company's robust operations in Latin America are complemented by local distributors in El Salvador, Bolivia, Guatemala and Honduras. In 2010, the company began to expand its operations outside of Brazil by means of local outsourcing, a process that in $201 \mathrm{I}$ repeated in Mexico and Colombia. As can be noted, the company's supply chain increases in complexity, which imposes challenges in SCM as well as in the reduction of the social and environmental impacts of its business model. This company displays a culture that values its relations and the insertion of sustainability in its business model, having obtained much recognition in Brazil and abroad for its behavior toward the sustainable use of Brazilian biodiversity.

Except in France, Natura adopts direct sales as its commercial model, offering development alternatives to more than 1.2 million consultants (direct sales representatives). Moreover, the company has more than seven thousand employees. In 2004, the company held an initial public offering: approximately $40 \%$ of its stock is available in the São Paulo Stock Exchange (BM\&FBovespa) in the New Market level, which requires increased corporate governance and transparency of available information. Since 2005, the company has been integrated in the Corporate Sustainability Index (ISE) of this stock exchange.

In 2010 , the company generated net revenues of $R \$ 5$. I billion (a $21.1 \%$ growth in relation to 2009) and an EBITDA of $R \$ 1.2$ billion (24.6\% growth relative to 2009), with an EBITDA margin of $24.5 \%$ (23.8\% in 2009). The company's net profits reached $\mathrm{R} \$ 744.1$ million (8.8\% greater than in 2009 ).

The company's target market in Brazil reached $\mathrm{R} \$ 19.6$ million in 2010 ( $13.5 \%$ greater relative to 2009), for which the company holds a $24 \%$ market share $(22.9 \%$ in 2009$)$. Its market is composed by the Fragrance and Cosmetic ( $R \$ 9.7$ million) and the Toiletry ( $\mathrm{R} \$ 9,9$ million) segments, for which the company's market share is $34.9 \%(1.2 \%$ in 2009$)$ and 13.3\% (0.4\% in 2009), respectively (Natura, $20 \mathrm{l} \mathrm{Ia).} \mathrm{In} \mathrm{Latin}$ America, considering the Cosmetic, Toiletry and Fragrance Industry which includes segments not considered in the company's business model (hair coloring, oral hygiene, diapers, nail polish, etc.), Natura holds a $10.1 \%$ market share. In countries where the company's operations are being consolidated (Argentina, Chile and Peru), its market share is 3.5\%; in countries with operations in implementation (Mexico and Colombia), it is $0.7 \%$; in Brazil, I4.4\% (Natura, $201 \mathrm{la}$ ).

ISSN: 07I 8-2724. (http://www.jotmi.org)

Journal of Technology Management \& Innovation (c) Universidad Alberto Hurtado, Facultad de Economía y Negocios. 


\section{I Innovation Power and Supply Chain Characteristics}

According to the Van Bommel (20II) framework, focal company characteristics that affect innovation power in supply chains are size and bargaining power, along with innovation characteristics in the focal company and supply chain cooperation, analyzed below. The company's investment in innovation is distributed to science and technology, innovation management and partnerships, product development and marketing, regulatory affairs management, and product safety. In 2010, investment in innovation reached $R \$ 139.7$ million, equivalent to $2.8 \%$ of the company's net revenues, the same proportion of 2008 and greater than that of 2009 (2.6\%). The main concerns in Natura's innovation agenda are presented in Figure 3.

Since 2005, Natura also operates through open innovation in order to develop new products, processes, and tools, through partnerships with science and research centers in Brazil and abroad. According to Chesbrough (2003; p.24) open innovation is a paradigm that assumes that firms can and should use external ideas as well as internal ideas, and internal and external paths to market. It assumes that internal ideas can also be taken to market through external channels beyond the company's usual operations in order to generate value for the company.According to this author, in this innovation model, the knowledge the company obtains through its research and development (R\&D) activities cannot be restricted to the company, as is typical of closed innovation models.
The company qualified 27 employees in innovation management in 2010 through an international certification program accredited by the Global Innovation Management Institute. Other training is offered to employees internally for the development of innovation competencies, including matters like technological convergence and sustainability, among others. In 2010, over 8,000 hours of training were given to Natura's internal public. The company monitors its development using an innovation index that compares gross revenues for the past 12 months from products that were launched in the past 24 months with total gross revenues for the past 12 months. In this same year, the innovation index reached $61 \%$, considered acceptable relative to the goal set by the company in its strategic management portfolio, which points that the ideal innovation index should vary between $55 \%$ and $65 \%$. It should be noted that this index reached 67.5\% in 2008 and 67.6\% in 2009 (Natura, 20l lb).

Natura's supply chain consisted of approximately 5,000 organizations in 2010 , of which $5 \%$ supplied inputs necessary for Natura's production lines. The rest of the suppliers were service providers or providers of biodiversity assets and indirect materials needed for business processes. The company states that collaboration in the supply chain is characterized by factors such as trust, reputation, joint programs and cooperative information systems. In its operations in Brazil, the company monitors its suppliers using satisfaction and loyalty indexes. In 2010, the company's satisfaction index was $81 \%$; its target is to increase this rate to $85 \%$. Its loyalty rate, which reached $28 \%$ in 2010 , consists of overall supplier satisfaction, intention to continue a relationship with Natura

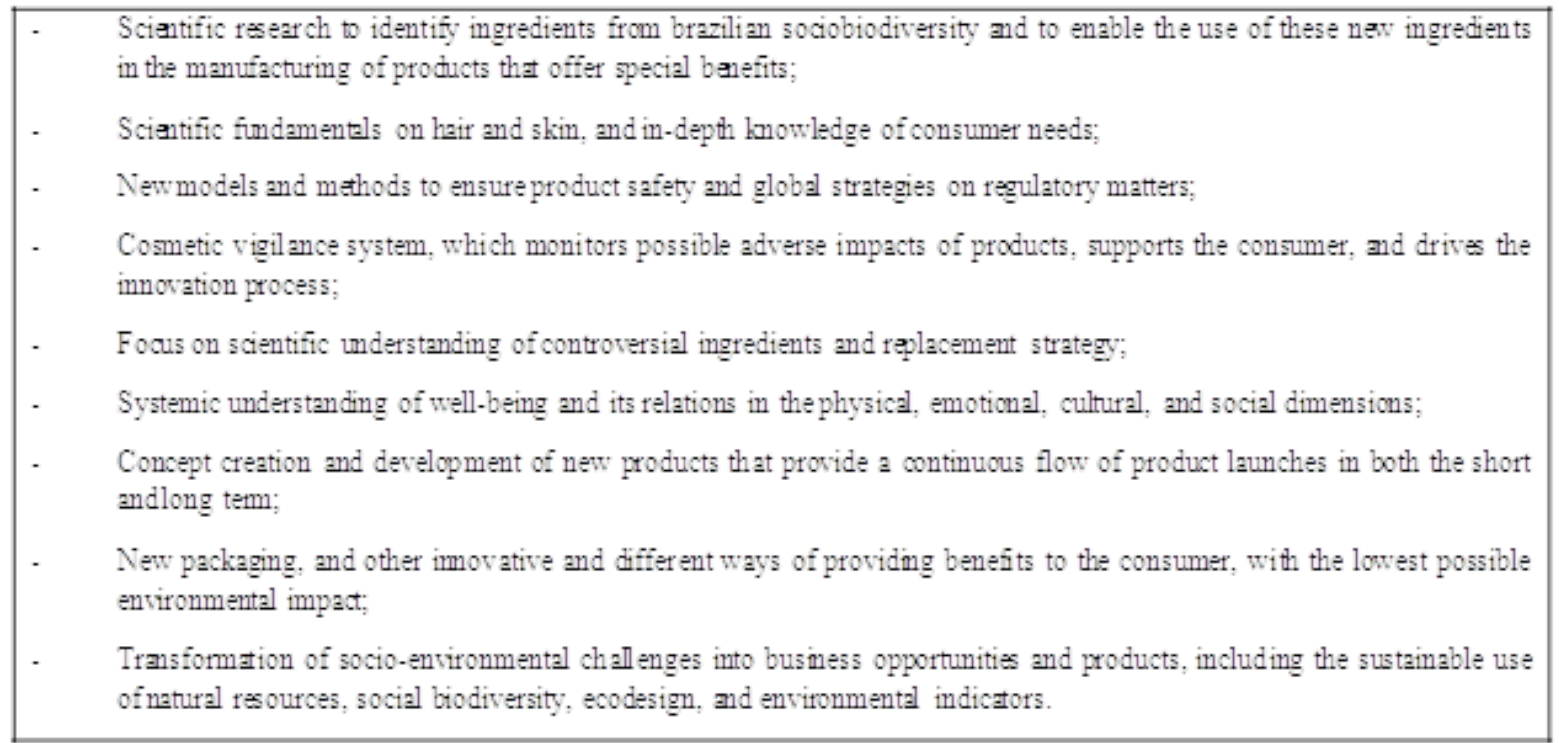

Figure 3 - Central matters in Natura's Innovation Agenda Source: Natura (20l lb)

ISSN: 07I 8-2724. (http://www.jotmi.org)

Journal of Technology Management \& Innovation (C) Universidad Alberto Hurtado, Facultad de Economía y Negocios. 
and willingness to recommend the brand to other organizations. Natura develops supplier integration and development programs to align suppliers with the precepts that guide the company. In 2010, four dialogue panels, which included representatives from national and international organizations, were held with suppliers to discuss solid waste, the relationship between suppliers and supplier communities, and sustainable supply chains. Meetings are held to monitor the performance of companies involved in the Qlicar Program (Quality, Logistics, Innovation, Competitiveness, Service and Relationship). Periodic meetings, such as the Alliance Conferences and Breakfast Meeting with Suppliers, are held with strategic partners in order to promote a closer relationship with suppliers and enable the process of co-construction with suppliers.

Despite the expansion of its operations to international markets, Natura's supplier base is found predominantly in Brazil. In the past years, the company has adopted a supplier development strategy in other Latin American countries using outsourced partnerships. This model (i) reduces costs and environmental impacts related to greenhouse gas (GHG) emissions by shortening the transportation distances of products usually produced in Brazil; (ii) values important relationship concepts for Natura, such as partnership and co-construction; and (iii) values organizations with local knowledge and good social and environmental practices. In 2010, the company initiated this model in Argentina with perfume-bottling activities. When the model is fully implemented, including in Mexico and Colombia, a projected $70 \%$ reduction in GHG emissions that result from supply logistics in these countries is expected (Natura, 20I l b).

Within the context of expansion of its activities in terms of physical reach and economic results, SCM becomes more complex, its social and environmental impacts, more dispersed, and the extension of life cycle increases. As such, in its product innovation processes, Natura has intensified the flow of information to suppliers and has established clearer project management rules, having created, in 2010, a department dedicated to internal innovation through SCM. Based on this information, the research found evidences of the innovation power of Natura, through its internal characteristics as well as through the attributes of its supply chain.

\subsection{The Strategies and Activities Associated with Innovation in the Supply Chain}

Given Natura's innovation power and its commitment to sustainability, it can be affirmed that the company does not adopt the resign strategy, depicted by Van Bommel (20II). The author points out that the offensive and defensive strategies are ambivalent, similar to the equivalent approaches proposed by Seuring and Müller (2008), SMRP and SCMSP, respectively. In Natura's practices, activities associated with the defensive/SMRP and offensive/SCMSP approaches can be identified, as will be examined below.

All productive suppliers undergo self-evaluation processes with respect to quality, environment and social responsibility which also includes aspects related human rights such as the use of child labor, forced labor or the equivalent of slave labor, discrimination based on race, creed, gender, etc. Human rights clauses are depicted in all contracts classified as significant investments: those that relate to investments over $R \$ 200,000$, intellectual property, real estate acquisitions, donations and sponsorships. In 2010, close to 2,200 contracts received this classification. $48 \%$ of productive suppliers underwent periodic audits, being that all 97 organizations participating in the Qlicar project, which deals with supplier development, were audited.

The imposition of requirements such as certification systems for minimum social and environmental practices characterizes the defensive/SMRP approach, shown previously. On the other hand, collaborative actions with suppliers are closer to the offensive/SCMSP strategy. An example of this is depicted by supplier training programs for (i) the elaboration of sustainability reports according to Global Reporting Initiative (GRI), in order to train and engage them in the incorporation of social and environmental concerns to business management; and (ii) quantification and management of GHG emissions, according to the guidelines of the Greenhouse Gas Protocol (GHG Procotol) (Natura, 20 l lb).

Attributes presented by Natura in many of its products demand the implementation of strategies that are aligned with the innovative offensive/SCMSP strategy profile. For example, Natura Ekos products are developed from clean or green technologies that seek to reduce environmental impacts throughout the supply chain: they have formulas that use plant products, which prioritize the use of renewable raw materials; use biodiversity assets whose origin can be traced or is certified, be it from organic farming or sustainable forest management; and use packaging that prioritize renewable materials or post-consumption recycled materials, or renewable inputs, such as refills made of green polyethylene, made from sugar cane. An important aspect of the offensive/SCMSP is to act as a pioneer in the search for innovation, as displayed by the company with respect to the use of green plastic in product packaging.

The use of plant products in the company's formulas seeks to substitute the use of raw materials of animal, mineral or synthetic origin for alternatives that are of plant origin, in order to reduce the environmental impact throughout the product's life cycle. Mineral oils commonly used in commercial cosmetic products originate from a mixture of hy- 
drocarbons obtained from the purification process of petroleum. However, since 2005, Natura uses palm olein as the main ingredient of plant oils and plant mass in soaps, as well as in three-phase and massage oils from its Ekos product line. This oil is $100 \%$ plant-based, produced in Brazil and cultivated without the use of chemical products; for this to occur, a strong integration with the supplier Agropalma was necessary.

To ensure that the inputs used as raw materials in the formulation of products are extracted in a sustainable manner and socially promote the extractive communities, Natura implemented the Program for the Certification of Ingredients in 2008 , with the goal of promoting sustainable cultivation and management of natural resources through the certification of native plantation and forests by third-party agents. Natura does not transfer certification costs to the supplier as it claims to demand certification in order to guarantee social and environmental sustainability in the earlier stages of the supply chain and to contribute to the continuous improvement of the process. Moreover, the company develops and maintains the relationship with supplier communities with regards to fair wage: prices paid for plant inputs should cover all production, processing and commercialization costs, including a fair return for the farmers and taking into consideration the management of cooperatives and associations and the expected taxes imposed upon each kind of commercialized product. The prices are defined using technical coefficients that are locally derived and agreed upon by groups involved with the production, in a collaborative manner.

Three different certification protocols are adopted according to the pecularities of each region and productive area: organic agriculture, sustainable agriculture and forestry, using the criteria set by the Biodynamic Institute (IBD), the Forest Stewardship Council (FSC) and the Sustainable Agriculture Network (SAN) (Natura, 20 I l b). From a total of I4 assets in the Ekos line, $80 \%$ are certified while the other $20 \%$ display certification plans for the next few years. The company supports local groups in certifying their assets, with the expectation that these groups will gain autonomy in the certification management of their assets after a few years. This support has been essential for the structuring of the supply chain of $65 \%$ of the certified raw materials in the Ekos product line, suggesting that the certification requirements can be considered an offensive/SCMSP strategy as they demand collaboration efforts to enable innovation as well as to structure the supply chain. As for the positive social impacts arising from this model, the production of inputs takes place through partnerships with rural suppliers, such as traditional communities and family farmers, who can contribute to biodiversity conservation and who benefit from the opportunity to connect to Natura's supply chain. These partnerships reached 19 rural communities, encompassing I,7I4 families, and 14 Brazilian biodiversity assets, whose supply and distribution of benefits generated over $\mathrm{R} \$ 8.5$ million in resources. As such, this model supports social development, the strengthening of the economy, social inclusion and environmental sustainability in these communities.

An innovation in this relationship is the distribution of resources for generic heritage and traditional knowledge. In 2008, Natura created the Policy for the Sustainable Use of Biodiversity and Cultural Heritage, which was fully implemented in 2009. This policy seeks to meet the guidelines of the Convention on Biological Diversity, signed by Brazil during the Earth Summit (ECO-92). This conference had as an objective the conservation of biodiversity, the sustainable use of its components and the just and equitable distribution of the benefits obtained from the use of genetic resources, including the appropriate access to these resources and the appropriate transfer of technology (article I). The access to biodiversity resources, such as, for example, a plant species with the potential of supplying new aromatic essences for cosmetic products, depends on government authorization from the country that has this resource which, in Brazil's case, is obtained from the Genetic Heritage Management Council, led by The Ministry of the Environment; moreover, the benefits must be shared with the local and indigenous communities that facilitated the access to the resources and shared practices and knowledge concerning these resources (article 8). Despite being regulated in Brazil and in other countries in which the company operates, there are various gaps in this process; Natura's Policy for the Sustainable Use of Biodiversity and Cultural Heritage seeks to fill these in a proactive manner. It is worth noting that this is a delicate matter for a company that has already found itself in highly publicized case involving traditional herb sellers from Vero-Peso, the most famous market of the Brazilian Amazon, placed in Belém, state of Pará.

All of the mentioned actions reflect strategies and activities that result from Natura's innovation power and supplier chain engagement with the intent of reducing the social and environmental impact of its products, throughout the product's life cycle, thereby increasing positive results in the three dimensions of sustainability: the economic, social and environmental. Regarding social and environmental issues, Natura is clearly not among most of Brazilian firms that, according to Gomes et al. (201 I, p. 124), still adopt a posture of focusing essentially on investments and regulation-related actions to meet the requirements and dictates of domestic and international standards. In short, with a basis in its innovation power, the company adopts the two strategies mentioned. Although they are different in terms of objectives and practices, they complement each other in the case study presented, as the company adopts the two strategies simultaneously in the same tiers of its supply chain. For 
example, its training programs and supplier education use both strategies.

\section{FINAL CONSIDERATIONS}

Sustainability is a word in vogue in the corporate world amidst a scenario in which competition between companies increasingly occurs within their supply chains in a model where goods become obsolete more quickly, or, present a shorter market life-cycle, thereby increasing the consumption of materials and of energy and intensifying the quantity of post-consumption waste globally. Not considering the debate about consumption, it is critical to generate solutions in global sustainability; a significant part of the contribution of the productive sector to the more sustainable development model takes place through the incorporation of social and environmental concerns, from the start of a product's innovation projects to the end of its useful life. This point of view demands that supply chain management approaches near the lifecycle management of a product, from cradle to grave, and that innovation go beyond the interorganizational environment, reaching direct and indirect members of the supply chain in a collaborative manner in order to seek solutions that reduce negative impacts throughout the chain and, when possible, enhance the business benefits in the three dimensions of sustainability.

The case study examined in this chapter points to evidences that the incorporation of sustainability in the business model, not only through the viewpoint of negative impacts but also of the development of solutions that bring value to the company and to society, is possible when the company aligns its strategic objectives in the social and environmental dimensions to its innovation power and engages current direct and indirect suppliers, as well as develops new partners in its initiatives to find innovation in products and processes. In this context, the intersection of the fields of studies of innovation and supply chain management greatly contributes to the sustainability research agenda. Frameworks that seek to integrate the two areas, such as Van Bommel (20l I), based on the Seuring and Müller model, begin to surge, but undoubtedly, still need to mature. The analysis of the induction of social and environmental practices by a focal company with an innovative profile, such as that of Natura, sought to contribute to this process, albeit the limitations of the methodology of this case study must be considered. Research opportunities in this area are present not only in comprehensive research studies of supply chains but also in the application of the frameworks examined in this work in larger groups of companies.

\section{REFERENCES}

BARBIERI, J.C., Andreassi, T., Vasconcelos, I.F.G.,Vasconcelos, F.C. (20I0). Inovação e sustentabilidade: novos modelos e proposições. Revista de Administração de Empresas, São Paulo, 50(2), I46-I54.

CARTER, C.R., Easton, P.L. (20I I). Sustainable supply chain management: evolution and future directions. International Journal of Physical Distribution \& Logistics Management, $4 I(I), 46-62$.

CARTER, C.R., Rodgers, D.S. (2008).A framework of sustainable supply chain management: moving toward new theory. International Journal of Physical Distribution \& Logistics management, 38(5), 360-387.

CARVALHO, A.P., Barbieri, J.C. (20I0). Sustentabilidade e gestão da cadeia de suprimento. In:Vilela Júnior, A., Demajorovic, J. (Eds.). Modelos e ferramentas de gestão ambiental: desafios e perspectivas para as organizações. Senac, São Paulo, pp. 40I-429.

CHESBROUGH, H. (2003). Open innovation: the new imperative for creating and profiting from technology. Harvard Business Press, Boston.

LAMBERT, D.M., Cooper, M.C., Pagh, J.D. (1998). Supply Chain Management: implementation issues and research opportunities. The International Journal of Logistics Management, 9(2), I-I9.

COOPER, M.C., Lambert, D.M., Pagh, J.D. (1997). Supply Chain Management: more than a new name for logistics. The International Journal of Logistics Management, 8(I), I- I4.

EISENHARDT, K. (1989). Building theories from case study research. The Academy of Management Review, 14(4), 532550.

ELKINGTON, J. (1998). Cannibals with forks: the triple bottom line of 2 Ist century business. New Society Publishers, Gabriola Island, British Columbia.

International Organization for Standardization - ISO. (2006). Environmental management - life cycle assessment - requirements and guidelines. ISO, Geneva.

GOMES, C.M., Kruglianskas, I., Scherer, F.L. (20I I). Innovation management for sustainable development practices in the internalization context. Journal of Technology Management and Innovation, 6(2), I I0-I27. 
KEMP, R., Pearson, P. (2008). Final report MEl project about measuring ecoinnovation. United Nations University Maastrich Economical and Social Research Institute on Innovation and Technology. http://www.merit.unu.edu/MEI/ deliverables/MEI\%20D I 5\%20Final\%20report\%20about\%20 measuring\%20eco-innovation.pdf [Accessed March II, 20I2].

KEMP, R., Arundel, A. (1998). Survey indicators for environmental innovation. Indicators and data for European analysis. Idea Project. http://survey.nifu.no/step/old/Projectarea/ IDEA/Idea8.pdf [Accessed March II, 20I2].

MENTZER, J., Dewitt,W., Kreebler, J., Min, S., Smith, C., Zacharia, Z. (200I). Defining supply chain management. Journal of Business Logistics, 22 (2), I-25.

Natura Cosméticos S.A. - NATURA. (20l la). Resultados do primeiro trimestre de 201 I, Natura's corporate website. http://natura.infoinvest.com.br/ptb/37/9/Press_ release_ITII.pdf [Accessed September 0I, 20I I].

Natura Cosméticos S.A. - NATURA. (20l lb). Relatório anual 2010, Natura's corporate website. http://scf.natura.net/ Conteudo/Default.aspx? MenuStructure $=5 \&$ Menultem $=12$ [Accessed September 0I, 20I I].

Organisation for Economic Co-operation and Development - OECD. (2005). Oslo manual guidelines for collecting and interpreting innovation data. Statistical Office of the European Communities, Paris.

SARKIS, J., Zhu, Q., Lai, K. (20I I).An organizational theoretic review of green supply chain management literature. International Journal of Production Economics, I 30 (I), I-I5.

SAVITZ,A.W., Weber, K. (2006). The triple bottom line: how today's best-run companies are achieving economic, social and environmental success and how you can too. John Willey \& Sons, San Francisco.

SEURING, S., Müller, M. (1998). From a literature review to a conceptual framework for sustainable supply chain management. Journal of Clean Development, 16, I699-1710.

SRIVASTAVA, S. (2007). Green supply-chain management: a state-of-the-art literature review. International Journal of Management Reviews, 9 (I), 53-80.

VAN BOMMEL, H.W.M. (20II). A conceptual framework for analyzing sustainability strategies in industrial supply networks from an innovation perspective. Journal of Cleaner Production, 19, 895-904.
YIN, R. (1994). Case Study Research: design and methods. Sage Publications, Thousand Oaks, California. 
J.Technol. Manag. Innov. 2012,Volume 7, Issue 2

ISSN: 07I8-2724. (http://www.jotmi.org)

Journal of Technology Management \& Innovation @ Universidad Alberto Hurtado, Facultad de Economía y Negocios. 